is no limit to the amount of work to be done in the world, the amount of business to be had or the amount of wealth that may be created from the resources of Nature. The great problem of society is neither one of class confliction, or of international rivalry, nor of general overproduction. The problem is to so organize, integrate and develop the resources and industries of all countries as to secure the greatest possible production and distribution of all those things that will minister to the comfort and welfare of all people of the world. That is the great appeal to the enlightened and constructive forces of the world!

\title{
OPPOSED DIVORCE BY LEGISLATIVE ACT
}

Gov. John Chambers: The theory of our government teaches that the most perfect security to liberty, and to individual rights, is to be found in the distribution of its powers among three distinct bodies of magistracy, and the confinement of each within the sphere prescribed by the constitution for its action. I submit then, that the concurrent exercise of the power to dissolve the bonds of matrimony, by the legislative and judicial departments, is a departure, and a dangerous one, from the principles of our government, and ought to cease. If the powers conferred by law upon the judiciary, are found too limited, let them be enlarged; still securing to the parties implicated, the unalienable and invaluable right of defending themselves, and of demanding the production of legal and competent evidence against them, before sentence of divorce is pronounced ... Too much facility and encouragement has been given to applications for legislative interposition in such cases, and satisfies me that it will be more safe and more consistent with the principles of our government to leave them to judicial action, than to continue to legislate for each particular case.-Message to House of Representatives, Feb. 14, 1843. 
Copyright of Annals of Iowa is the property of State of Iowa, by \& through the State Historical Society of Iowa and its content may not be copied or emailed to multiple sites or posted to a listserv without the copyright holder's express written permission. However, users may print, download, or email articles for individual use. 